\title{
INHIBITION OF CYCLOOXYGENASE-2 IN EXPERIMENTAL SEVERE ACUTE PANCREATITIS
}

\author{
José Luiz Jesus de Almeida, José Jukemura , Ana Maria Mendonça Coelho, \\ Rosely Antunes Patzina, Marcel Cerqueira César Machado, José Eduardo \\ Monteiro da Cunha
}

de Almeida JLJ, Jukemura J , Coelho AMM, Patzina RA, Machado MCC , Cunha JEM. Inhibition of Cyclooxygenase-2 in Experimental Severe Acute Pancreatitis. Clinics. 2006;61(4):301-6.

BACKGROUND: The standard treatment for acute pancreatitis (AP) is still based on supportive care. The search for a new drug that could change the natural history of the disease is a continuing challenge for many researchers. The aim of this study is to evaluate the effect of a cyclooxygenase-2 (COX-2) inhibitor on experimental AP in rats.

METHODS: The animals were divided into 2 groups: Group $1(\mathrm{n}=30)$-animals with taurocholate-induced AP treated with parecoxib $(40 \mathrm{mg} / \mathrm{kg})$. Group $2(\mathrm{n}=30)$-animals with taurocholate-induced AP that received saline. The COX-2 inhibitor (parecoxib) was injected immediately after AP induction, through the penis dorsal vein. The parameters evaluated were histology, serum levels of amylase, IL-6 and IL-10, and mortality rate. RESULTS: The serum levels of IL-6 and IL-10 in the parecoxibtreated group were lower than the control group. The amylase serum levels and the mortality rate remained unchanged in the treated animals. Histologic morphology also was unaltered, except for fat necrosis, which was higher in parecoxib-treated rats. CONCLUSION: Inhibition of Cox-2 decreases the systemic release of inflammatory cytokines, but has a poor effect on the direct pancreas injury caused by taurocholate.

KEYWORDS: Acute pancreatitis, COX-2 inhibition, Parecoxib, Interleukins

\section{INTRODUCTION}

Acute pancreatitis (AP) is an inflammatory condition of the pancreas characterized by abdominal pain and elevated pancreatic enzymes in the blood. ${ }^{1}$ There are several etiologies for this disturbance, ${ }^{2}$ but the exact pathophysiological mechanism is still not completely understood.

The disease involves a complex cascade of events. ${ }^{2-5}$ It starts with intracellular activation of enzymes and the subsequent lesion of acinar cells, leading to a local and systemic inflammatory response. ${ }^{2}$ Activation of complement and secondary release of $\mathrm{C} 5 \mathrm{a}$ has a significant role in the recruitment of inflammatory cells. ${ }^{3}$ Activation of these cells pro-

Department of Gastroenterology, Department of Surgery and Department of Pathology - University of São Paulo, Faculty of Medicine, São Paulo, Brazil Email: josluizalmeida@yahoo.com.br

Received for publication: December, 21, 2005.

Accepted for publication: April, 12, 2006. vokes the release of proinflammatory cytokines, metabolites of arachidonic acids, and oxygen free radicals (OFRs), which may eliminate the antioxidant defenses of the cells. ${ }^{5}$ These substances interact with the microcirculation, increasing vascular permeability and inducing thrombosis and hemorrhage, ultimately leading to tissue necrosis.

The cyclooxygenase (COX) enzyme (also known as PGH syntase or PG endoperoxydase) catalyzes the limiting reaction of prostaglandin $\mathrm{E}_{2}$ production. ${ }^{6}$ There are at least 2 isoforms of cyclooxygenases. ${ }^{7}$ The isoform known as COX-1 is constitutive (present in several healthy tissues, such as the kidneys and the gastrointestinal tract). It is believed that this isoform has a pivotal role in the protection and maintenance of mucosal integrity. ${ }^{8}$ The isoform COX2 is inducible, and its detection in noninflamed tissues is controversial. It also appears to play a role in the course of inflammation . ${ }^{9}$ The expression of COX-2 is stimulated by proinflammatory cytokines, such as TNF-alpha and IL- 
1 ; it is inhibited by anti-inflammatory mediators, such as interleukin-10 (IL-10), IL-4, and by the transforming growth factor-beta (TGF-beta). ${ }^{10,11}$

Zabel-Langhennig et al demonstrated that COX-2 mRNA as well as its serum level are elevated in the setting of AP. ${ }^{12}$ This elevation is more pronounced in the early stages of the inflammatory process, when the enzyme acts as a proinflammatory agent. In the late stages of the disorder, COX-2 may have anti-inflammatory properties, although this still is matter of debate..$^{13}$

Other studies have shown the beneficial effect of previous inhibition of COX-2 or the knock-out of its gene in experimental AP. ${ }^{14-17}$ Song et al, ${ }^{16}$ using a model of experimental cerulein-induced AP, showed that pharmacological inhibition of COX-2 before AP induction resulted in the reduction of inflammatory mediators, in diminished neutrophil recruitment, and in improvement of pulmonary and pancreatic histologic lesions. However, the efficacy of COX-2 inhibition has not yet been evaluated in a clinical setting; moreover, some reports have shown an association of administration of COX-2 inhibitor and AP. ${ }^{18-21}$

Taking this controversy into account, the aim of this study was to determine the effect of COX-2 inhibition on experimental taurocholate-induced AP.

\section{MATERIALS AND METHODS}

Sixty male Wistar rats, provided by the Medical Investigation Laboratory \#37 (LIM-37) and managed according to Guide for Care and Use of Laboratory Animals (1996) were used. The study protocol was approved by Institutional Ethics Committee for animal use in research studies. The animals were housed in a room with a temperature of 23 $\pm 1^{\circ} \mathrm{C}$ and a 12-hour light-dark cycle. The night before the experiment, food and water was offered ad libitum.

Rats were divided into 2 groups: Group I $(\mathrm{n}=30)$ : rats with taurocholate-induced AP that received a single dose of parecoxib $(40 \mathrm{mg} / \mathrm{kg})$ iv through the penis dorsal vein immediately after the induction of AP; Group II $(n=30)$ : rats with taurocholate-induced AP that received a saline injection immediately after AP induction.

\section{AP induction}

We induced acute pancreatitis according to a previously reported procedure ${ }^{22}$ (Figure 1).

\section{Sacrifice}

After a 2-hour period, 10 rats of each group were reanesthetized and underwent a new laparotomy in order to

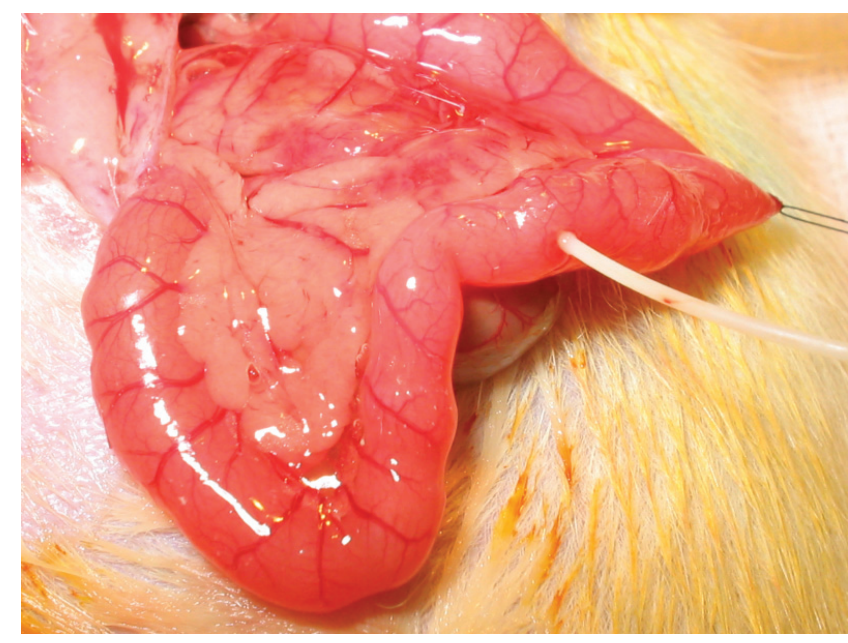

Figure 1- Injection of taurocholate into the main pancreatic duct (MPD)

obtain blood samples (by cardiac puncture) and pancreatic tissue. The pancreata were removed and carefully dissected, freed of all adjacent fat and lymph nodes. The animals were sacrificed by exsanguination after this process.Histologic alterations and serum levels of IL-6, IL-10, and amylase were assessed.

The remaining 20 rats of each group were watched for a 72-hour period to determine the mortality rate.

\section{Amylase and Interleukin Serum Levels}

Blood samples were immediately centrifuged at 3000 g for 10 minutes at $0^{\circ} \mathrm{C}$, and the supernatant stored at $-20^{\circ} \mathrm{C}$. In all rats, amylase serum levels were assessed by Bernfeld's method ${ }^{23}$ as modified by Jamieson et al. ${ }^{24}$

Serum IL-6 and IL-10 levels were determined by enzyme-linked immunoabsorbent assay (ELISA), using BioSource International Cytoscreen ${ }^{\mathrm{TM}}$ kits (BioSource International, Camarillo, California, USA)

\section{Histological Evaluation}

Representative tissue samples collected from the duodenal (proximal) and splenic (distal) parts of the pancreas were fixed in $10 \%$ formalin for $24 \mathrm{~h}$ and embedded in paraffin. Five-micrometer-thick sections were stained with hematoxylin and eosin, and the degree of tissue damage was graded in a blinded fashion by a single pathologist, using an established scoring system. ${ }^{25}$ Statistical Analysis

Results are reported as mean \pm SE. Parametric data were evaluated by the Student $t$ test. Nonparametric data were evaluated by the Mann-Whitney $\mathrm{U}$ test. To compare mortality rates, the Kaplan-Meier log-rank test was employed. Significant difference was declared when $\mathrm{P}<0.05$. 


\section{RESULTS}

Serum levels of IL-6 and IL-10 were lower in rats that received the COX-2 inhibitor, (Figures 2 and 3). In contrast, the ratio of IL-6 to IL-10 was unaltered.

Histologic evaluation of edema, hemorrhage, and acinar necrosis did not show any difference between the two groups, but fat necrosis was worse in the parecoxib-treated rats (Table 1).

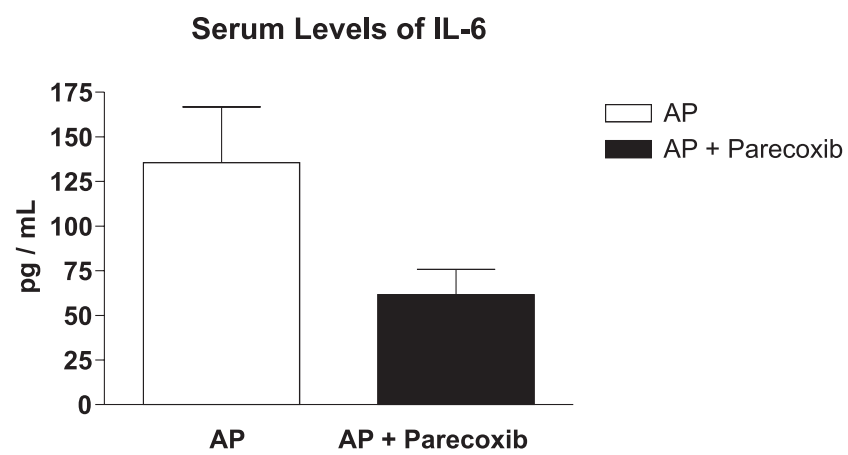

Figure 2- Effect of Cox-2 inhibition on serum levels of IL-6, evaluated by an ELISA method, showing lower levels in parecoxib-treated rats (AP: Mean $\pm \mathrm{SEM}=135.6 \pm 31.14, \mathrm{n}=7$; and $\mathrm{AP}+$ Parecoxib: Mean $\pm \mathrm{SEM}=61.64 \pm$ $14.19, \mathrm{n}=14(P=0.0216)$.

\section{Serum levels of IL-10}

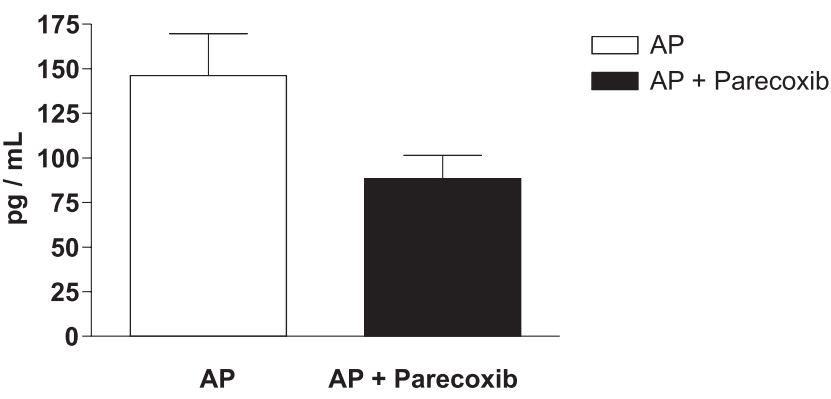

Figure 3. Effect of Cox-2 inhibition on serum levels of IL-10, evaluated by an ELISA method, showing lower level in parecoxib-treated rats (AP - Mean \pm SEM $=146.3 \pm 23.48, \mathrm{n}=8$ and $\mathrm{AP}+$ Parecoxib - Mean $\pm \mathrm{SEM}=88.43 \pm$ 12.93, $\mathrm{n}=14$ with $\mathrm{p}=0.0288$ ).

Table 1. Effect of Cox-2 inhibition on fat necrosis, according to Schmidt's scale, ${ }^{30}$ showing higher fat necrosis in parecoxib-treated rats $(P=0.0 .0289)$.

\begin{tabular}{cc}
\hline Acute Pancreatitis & Acute Pancreatitis + Parecoxib \\
\hline 0.0 & 2.0 \\
0.0 & 2.0 \\
0.0 & 2.0 \\
1.0 & 2.0 \\
1.0 & 2.0 \\
1.0 & 1.0 \\
1.0 & 0.0 \\
\hline
\end{tabular}

Serum levels of amylase and mortality rates remained unaltered (Figure 4).

\section{2-Hour Survival Rate}

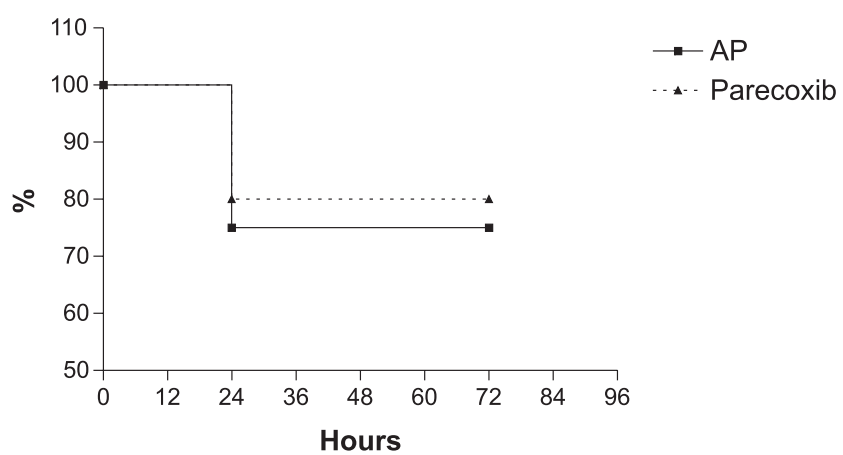

Figure 4- Effect of Cox-2 inhibition on mortality rate, showing a better late survival rate in parecoxib-treated rats, but with no significant difference between the groups $($ Chi square $=0.1398 ; P=0.7085 ; \mathrm{n}=20$ ).

\section{DISCUSSION}

The standard treatment of AP is still based on supportive care ${ }^{26}$. The search for new drugs that could alter the natural history of the disease is a continuing challenge for many researchers. Several substances have been tested in some studies in an attempt to block the effects of inflammatory mediators that have an established role in the pathogenesis of AP. The tested agents include antioxidants, antiplatelet aggregating factor (anti-PAF), nonspecific COX-inhibitors, $\mathrm{H}^{+} \mathrm{K}^{+}$pump inhibitors, and somatostatineanalogues. ${ }^{27-31}$ The drawback of these studies is that, in general, the treatment was carried out before the induction of AP, and although some of these substances may have brought some benefits in experimental AP models, application in the clinical setting is limited by the impossibility of predicting the occurrence of the disease. On the other hand, in the present study, the aim was to determine whether the activity of COX-2 is relevant to the progression of the disease. Therefore, the COX-2 inhibitor parecoxib was administered immediately after the onset of $\mathrm{AP}$, which also does not directly relate to the real clinical scenario. Nevertheless, this has allowed us to highlight important findings about the role of COX-2 in the pathophysiology of the disease.

COX-2 is considered a proinflammatory enzyme that is expressed in the early phases of inflammation (neutrophil-dominated phase). Much is known about the proinflammatory role of COX-2 in a variety of acute and chronic inflammatory conditions, including arthritis, inflammatory bowel disease, and asthma, but very little is known regarding its potential role in acute pancreatitis. In 
a study using a cerulein model of severe AP, Song et al found that mRNA levels of pancreatic COX-2 rose within 15 minutes of the start of cerulein administration and that pancreatic COX-2 protein levels were increased within 4 $\mathrm{h}$ of cerulein administration. ${ }^{16}$ These observations suggest that COX-2 might play an important role in regulating the severity of cerulein-induced AP. However, the mechanisms by which COX-2 might promote inflammation in taurocholate-induced AP are not immediately obvious. We considered the possibility that COX-2 might cause direct damage to epithelial ductal cells and recruit inflammatory cells to the local tissue, leading to edema and hemorrhage. Cytokine production by these inflammatory cells probably involves activation of nuclear factor $-\kappa B(N F-\kappa B){ }^{32}$ The proinflammatory effects of COX-2 in experimental AP may be multifactorial and involve, among other things, alterations in heat-shock proteins (HSPs), inducible NO synthase (iNOS) expression, and neutrophil function.

In the present study, we demonstrated that parecoxib, a second generation COX-2 inhibitor, infused immediately after AP induction, diminished serum levels of IL- 6 and IL-10; however, there was no decrease of serum levels of amylase or any benefit regarding pancreatic histologic damage, and the survival rate remained unaltered. Therefore, we postulate that the pancreatic lesion established in the taurocholate model of AP may be impossible to revert and, perhaps, that treatment should be directed to the prevention of the systemic damage. In an analogue study, Alhan et $\mathrm{al}^{17}$ found that celecoxib (a first-generation COX-2 inhibitor), injected i.p. 6 hours after the induction of necrotizing AP, decreased myeloperoxidase (MPO) and malondialdehyde (MDA) levels in the pancreatic tissue. These authors concluded that celecoxib has an antioxidant effect, because there is no evidence that prostaglandins contribute to acinar cell injury. In addition, serum levels of IL6 were also found to be reduced, and no differences in mortality rate were observed. In our study, the COX-2 inhibitor was injected intravenously immediately after AP induction. The dosage we employed was 4-fold higher than previously reported by other authors ${ }^{14,16}$ The option for such a huge dosage was purely empiric, as an attempt to maintain very low levels of COX-2.

Considering the proinflammatory action of IL-6, the reduction of its blood levels after the onset of AP, could have, in theory, beneficial effect in the evolution of the disease, even hours after induction. However, this could not be demonstrated by histologic evaluation in the present investigation. The role of IL- 6 on AP is complex and controversial. ${ }^{33}$ Multiple studies have correlated the severity of the disease with IL-6 blood levels. Some of these studies have suggested that levels of IL- 6 in patients with acute pancreati- tis may be predictive of disease severity. ${ }^{34-36}$ It has also been found that IL-6 is responsible for the synthesis of acutephase proteins. ${ }^{37}$

The cytokine IL-6, is thought to be induced, at least partially, by NF- $\kappa B$ activation. Slogoff et al, using a cerulein model of AP, showed that IL-6 levels were elevated in mice treated with COX-2 inhibitors, despite attenuated pancreatic inflammation and a decrease in NF- $\mathrm{KB}$ activation. ${ }^{38}$ This finding suggests that the stimulus for IL- 6 secretion remained intact, despite a lower NF- $\mathrm{KB}$ activity; however, it did not elucidate whether IL-6 is linked to the amelioration of AP in mice. In the present report, although serum levels of IL-6 were diminished, this was not associated with any benefit regarding the pancreatic histologic damage. On the other hand, in the report by Alhan et al, ${ }^{17}$ the lower level of IL-6 correlated with a lower level of MPO and MDA in the pancreatic tissue. This discrepancy observed among the 3 studies may be due to the differences in the experimental models as well as in the study designs.

Previous studies demonstrated that the kinetics of NF$\kappa \mathrm{B}$ activation after induction of cerulein-induced pancreatitis are biphasic; NF- $\kappa B$ is initially activated during the first 15 minutes after cerulein administration, peaks at 30 minutes, decreases during the next hour; a second peak occurs between 3 and 6 hours..$^{39}$ Considering these results, it is possible that the initial peak of NF- $\mathrm{KB}$ remains intact after COX2 inhibition in the cerulein model, thus resulting in IL-6 release. Nevertheless, the kinetics of NF- $\mathrm{KB}$ activation and IL6 release in taurocholate-induced AP is not clear.

Improved survival has been demonstrated in an experimental model of taurocholate-induced AP in rats treated with a NF- $\kappa B$ inhibitor, despite a lack of attenuation of histologic severity. ${ }^{40} \mathrm{So}$, it is also possible that there is no correlation between COX-2 and the NF- $\mathrm{KB}$ pathway in the early events of this experimental model.

With IL-10 being an anti-inflammatory cytokine ${ }^{42}$ and one of the major mediators of compensatory anti-inflammatory response syndrome, ${ }^{43}$ the decrease in its level after parecoxib treatment was an unexpected finding in the present study. This could explain the unchanged histologic damage and survival rate. There are some possible explanations for this result. As previously mentioned, anti-inflammatory cytokines, such as IL-10, decrease cyclooxygenase- 2 expression. Because COX-2 was already inhibited by parecoxib, it is possible that its serum levels were decreased since there was no stimulus for its increase. Perhaps the main reason for a compensatory anti-inflammatory response by IL-10 is the COX-2 activity itself. Another possibility is that the increase of IL-10 is coupled with an increase in IL-6 as a mechanism to keep the inflammatory response under control. The finding that the ratio of 
IL-6 to IL-10 was also unchanged suggests that the two cytokines decreased in a way directly proportional. Some studies have shown that increases in IL-10 concentration also follow a biphasic pattern (in the first days and about 10 days later). ${ }^{44}$ However, the significance of elevated serum IL-10 levels in AP is unclear, as is its connection with the COX-2 pathway.

In conclusion, the treatment with a COX-2 inhibitor might lower serum levels of at least two cytokines, but there was no amelioration of the survival rate or histologic pancreatic damage. The potential benefits of this effect are still unclear; therefore, further investigation is needed to better elucidate how COX-2 inhibition might change the natural course of AP.

Note: the authors would like to express their gratitude for Sandra Aparecida Nassa Sampietre and Nilza Aparecida Trindade Molan. We are in debt with them.

\section{RESUMO}

de Almeida JLJ, Jukemura J , Coelho AMM, Patzina RA, Machado MCC , Cunha JEM. Inibição da Ciclo-Oxigenase2 na Pancreatite Aguda Grave Experimental. Clinics. 2006;61(4):301-6.

INTRODUÇÃO: O tratamento padrão para a pancreatite aguda permanece baseado em medidas de suporte. A busca por uma droga que altere a história natural da doença ainda é um desafio para muitos pesquisadores. O objetivo deste estudo é avaliar o efeito de um inibidor da COX-2 na pancreatite aguda grave experimental (PA) em ratos.

MÉTODO: Os animais foram divididos em dois Grupos: Grupo $1(n=30)$ - animais com PA induzida por taurocolato e tratados com parecoxib $(40 \mathrm{mg} / \mathrm{Kg})$. Grupo $2(\mathrm{n}=30)$ animais com PA induzida por taurocolato que receberam solução salina. O inibidor de COX-2 (parecoxib) foi injetado imediatamente após a indução, através da veia dorsal do pênis. Os parâmetros avaliados foram histologia, níveis séricos de amilase, IL-6 e IL-10 e taxa de mortalidade.

RESULTADOS: Os níveis séricos de IL-6 e IL-10 foram menores do que no grupo controle. Os níveis séricos de amilase e a taxa de mortalidade permaneceram inalteradas. A análise histológica também não mostraram alterações, exceto pela necrose gordurosa, que foi maior nos animais controle.

CONCLUSÃO: A inibição da COX-2 pode reduzir a liberação sistêmica de pelo menos duas citocinas, mas tem pouco efeito na lesão pancreática direta causada pelo taurocolato.

UNITERMOS: Pancreatite aguda, Inibição da COX-2, Parecoxib, Interleucinas

\section{REFERENCES}

1. Dervenis C, Johnson CD, Bassi C, Bradley E, Imrie CW, Mcmahon MJ, et al. Diagnosis, objective assessment of severity and management of acute pancreatitis. Santorini Consensus Conference. Int J Pancreatol. $1999 ; 25: 195-210$

2. Bhatia M, Wong FL, Cao Y, Lau HY, Huang J, Puneet P, et al. Pathophysiology of acute pancreatitis. Pancreatology. 2005;5:132-44.

3. Formela LJ, Galloway SW, Kingsworth AN. Inflammatory mediators in acute pancreatitis. Br J Surg. 1995;82:6-13.

4. Norman JG. New approaches to acute pancreatitis: role of inflammatory mediators. Digestion. 1999;60:S57-S60.

5. Saluja AK, Steer MLP. Pathophysiology of pancreatitis. Role of cytokines and mediators of inflammation. Digestion. 1999;60:S27-S33.

6. Smith WL, Song I. The enzymology of prostaglandin endoperoxydase H syntase-1 and 2. Prostaglandins Other Lipid Mediat. 2002;68-69:11528.
7. Warner TD, Mitchell JA. Cyclooxygenases: new forms, new inhibitors, and lessons from the clinic. FASEB J. 2004;18:790-804.

8. Pairet M, Engelhardt G. Distinct isoforms (COX-1 and COX-2) of cyclooxygenase: possible physiological and therapeutic implications. Fundam Clin Pharmacol. 1996;10:1-17.

9. Turini ME, DuBois RN. Cyclooxygenase-2: a therapeutic target. Annu Rev Med. 2002; 53:35-57.

10. Huang ZF, Massey JB, Via DP. Differential regulation of cyclooxyegnase-2 (Cox-2) mRNA stability by interleukin-1 beta (IL1beta) and tumor necrosis factor-alpha (TNF-alpha) in human in vitro differentiated macrophages. Biochem Pharmacol. 2000;59:187-94.

11. Wu KK. Control of cyclooxygenase transcriptional activation by proinflammatory mediators. Prostaglandins Leukot Essent Fatty Acids. 2005;72:89-93. 
12. Zabel-Langhennig A, Holler B, Engeland K, Mössner J. Cyclooxygenase-2 transcription is stimulated and amylase secretion is inhibited in pancreatic acinar cells after induction of acute pancreatitis. Biochem Biophys Res. 1999;265:545-9.

13. Colville-Nash PR, Gilroy DW. Potential adverse effects of cyclooxygenase-2 inhibition: evidence from animal models of inflammation. BioDrugs. 2001;15:1-9.

14. Ethridge RT, Chung DH, Slogoff M, Ehlers RA, Hellmich MR, Rajaraman S, et al. Cyclooxygenase-2 gene disruption attenuates the severity of acute pancreatitis and pancreatitis-associated lung injury. Gastroenterology. 2002;123:1311-22.

15. Foitzik T, Hotz B, Witting F, Buhr HJ. Selective inhibition of cyclooxygenase-2 (COX-2) reduces prostaglandin E2 production and attenuates systemic disease sequelae in experimental pancreatitis. Hepatogastroenterology. 2003;50:1159-62.

16. Song AM, Bhagat L, Singh VP, Van Acker GGD, Steer ML, Saluja AK. Inhibition of cyclooxygenase-2 ameliorates the severity of pancreatitis and associated lung injury. Am J Physiol Gastrointest Liver Physiol. 2002;283:1166-74.

17. Alhan E, Kalyoncu NI, Ercin C, Kural BV. Effects of the celecoxib on the acute necrotizing pancreatitis in rats. Inflammation. 2004;28:303-9.

18. Nind G, Selby W. Acute pancreatitis: a rare complication of celecoxib. Inter Med J. 2002,32:624-25.

19. Carrillo-Jimenez R, Numberger M. Celecoxib induced pancreatitis and hepatitis: a case report. Arch Intern Med. 2000,160:553-4.

20. Baciewicz AM, Sokos DR, King TJ. Acute pancreatitis associated with celecoxib. Ann Intern Med. 2000;132:680.

21. Amaravadi RK, Jacobson BC, Solomon DH, Fischer MA. Acute pancreatitis associated with rofecoxib. Am J Gastroenterol. 2002;97:1077-8.

22. Lankisch PG, Ihse I. Bile-induced acute experimental pancreatitis. Scand J Gastroenterol. 1987;22:257-60.

23. Bernfeld P. Amylase. Methods Enzymol. 1955;1:149-50.

24. Jamieson AD, Pruitt KM, Calwell RC. An improved amylase assay. J Dent Res. 1969;48:483.

25. Schmidt J, Rattner DW, Lewandrowski K, Compton CC, Mandavilli U, Knoefel WT, et al. A better model of acute pancreatitis for evaluating therapy. Ann Surg.1992;215:44-56.

26. Amico EC, Canedo LF, Machado CC, Faria SG, Vivas DV. Conservative treatment of pancreatic necrosis with suggestive signs of infection. Clinics.2005; 60:429-432

27. de Souza LJ, Sampietre SN, Assis RS, Knowles CH, Leite KR, Jancar S, et al. Effect of platelet-activating factor antagonists (BN-52021, WEB2170, and BB-882) on bacterial translocation in acute pancreatitis. J Gastrointest Surg. 2001;5:364-70.

28. Salem MZ, Cunha JE, Coelho AM, Sampietri SN, Machado MC, Penteado S, et al. Effects of octreotide pretreatment in experimental acute pancreatitis. Pancreatology. 2003;3:164-8.

29. Abdo EE, Machado MC, Coelho AM, Sampietre SN, Leite KR, Molan NA, et al. Antioxidative effect of N2-mercaptopropionylglycine (N2MPG) in experimental acute pancreatitis. Rev Hosp Clin Fac Med Sao Paulo. 1998;53:169-73.
30. Montagnini AL, Kubrusly MS, Coelho AM, Molan NA, da Cunha JE, Machado MC, et al. Effect of omeprazole administration on pancreatic content of enzymes in rats. Rev Hosp Clin Fac Med Sao Paulo. 1995;50:272-5.

31. Jancar S, Abdo EE, Sampietre SN, Kwasniewski FH, Coelho AM, Bonizzia A, et al. Effect of PAF antagonists on cerulein-induced pancreatitis. J Lipid Mediat Cell Signal. 1995;11:41-9.

32. Steinle AU, Weudenbach H, Wagner M, Adler G, Schmid RM. NFkappaB/Rel activation in cerulein pancreatitis. Gastroenterology. 1999;116:420-30.

33. Heath DI, Cruickshank A, Gudgeon M, Jehanli A, Shenkin A, Imrie CW. Role of interleukin-6 in mediating the acute phase protein response and potential as an early means of severity assessment in acute pancreatitis. Gut. 1993;34:41-5.

34. Inagaki T, Hoshino M, Hayakawa T, Ohara H, Yamada T, Yamada H, et al. Interleukin-6 is a useful marker for early prediction of the severity of acute pancreatitis. Pancreas. 1997;14:1-8.

35. Pezzilli R, Billi P, Miniero R, Fiocchi M, Cappelletti O, Morselli-Labate AM, et al. Serum interleukin-6, interleukin-8, and beta 2-microglobulin in early assessment of severity of acute pancreatitis. Comparison with serum C-reactive protein. Dig Dis Sci. 1995;40:2341-8.

36. Berney T, Gasche Y, Robert J, Jenny A, Mensi N, Grau G, et al. Serum profiles of interleukin-6, interleukin-8, and interleukin-10 in patients with severe and mild acute pancreatitis. Pancreas. 1999;18:371-7

37. Leser HG, Gross V, Scheibenbogen C, Heinisch A, Salm R, Lausen M, et al. Elevation of serum interleukin- 6 concentration precedes acutephase response and reflects severity in acute pancreatitis. Gastroenterology. 1991;101:782-5.

38. Slogoff MI, Ethridge RT, Rajaraman S, Mark Evers B. Cox-2 inhibition results in alterations in nuclear factor (NF)-kappaB activation but not cytokine production in acute pancreatitis. J Gastronintes Surg. 2004;8:511-9.

39. Gukovsky I, Gukovskaya AS, Blinman TA, Zaninovic V, Pandol SJ. Early NF- $\kappa \mathrm{B}$ activation is associated with hormone-induced pancreatitis. Am J Physiol. 1998;275:G1402-14.

40. Satoh A, Shimosegawa T, Fujita M, Kimura K, Masamune A, Koizumi $\mathrm{M}$ et al. Inhibition of nuclear factor-kappaB activation improves the survival of rats with taurocholate pancreatitis. Gut. 1999;44:253-8.

41. Pestka S, Krause CD, Sarkar D, Walter MR, Shi Y, Fisher PB. Interleukin10 and related cytokines and receptors. Annu Rev Immunol. 2004; 22:929-79.

42. Braat H, Peppelenbosch MP, Hommes DW. Interleukin-10-based therapy for inflammatory bowel disease. Expert Opin Biol Ther. 2003;3:725-31.

43. Van Laethem JL, Esknazi R, Rickaert F, Robberecht P, Deviere J. Multisystemic production of interleukin 10 limits the severity of acute pancreatitis in mice. Gut. 1998;43:408-13.

44. Wereszczynska-Siemiatkowska U, Dabrowski A, Siemiatkowski A, Mroczko B, Laszewicz W, Gabryelewicz A. Serum profiles of e-selectin, interleukin-10, and interleukin-6 and oxidative stress parameters in patients with acute pancreatitis and nonpancreatic acute abdominal pain. Pancreas. 2003,26:144-52. 